\title{
PENDEKATAN HEALING ENVIRONMENT DALAM PERANCANGAN FASILITAS KESEHATAN MENTAL DI JOHAR BARU
}

\author{
Margareta Viannie Herwanto ${ }^{1)}$, Diah Anggraini ${ }^{2)}$ \\ 1)Program Studi S1 Arsitektur, Fakultas Teknik, Universitas Tarumanagara, viannieherwanto@gmial.com \\ 2) Program Studi S1 Arsitektur, Fakultas Teknik, Universitas Tarumanagara, diaha@ft.untar.ac.id
}

Masuk: 20-01-2021, revisi: 21-02-2021, diterima untuk diterbitkan: 26-03-2021

\begin{abstract}
Abstrak
Jakarta merupakan kota yang berkembang pesat dengan pembangunan permukiman dan infrastruktur yang berkelanjutan. Suatu keadaan yang menuntut peningkatan kepadatan kota, seakan tidak menyisakan tempat bagi penduduknya untuk bernafas. Masyarakat cenderung beraktivitas secara fungsional tanpa sempat memikirkan aktivitas lain seperti berinteraksi atau bersosialisasi. Penduduk Kota Jakarta, terutama pada kelompok berpenghasilan rendah dan tinggal di permukiman padat, sebagaimana di Kelurahan Johar Baru Jakarta Pusat terdapat peningkatan jumlah kasus stress dan depresi. Antara ruang dan kesehatan psikologis manusia memiliki hubungan yang erat dalam proses pemulihan. Bagaimana arsitektur dapat berperan dalam membantu proses penyembuhan seseorang, melalui stimulasi yang mentrigger pelepasan hormon dari otak manusia sebagai brain pharmaceuticals. Studi ini bertujuan menghasilkan suatu konsep dan rancangan bangunan fasilitas kesehatan mental yang dapat membantu masyarakat dalam mencegah dan mengatasi stress baik dalam skala komunitas maupun individu. Dengan menggunakan metode healing environment, desain akan menekankan konektivitas baik secara langsung dan tidak langsung antara lingkungan, bangunan dan manusia. Sehingga dapat menunjang proses healing dari perasaan tertekan, depresi dan stress penggunanya.
\end{abstract}

Kata kunci: arsitektur penyembuhan; urban stress; lingkungan natural; ruang publik

\begin{abstract}
Jakarta is a city that is growing rapidly with the development of settlements and infrastructure that continues to develop. A situation that demands an increase in the density of the city, as if leaving no place for its residents to breathe. People tend to be motivated to move functionally without having time to think about other activities such as interacting or socializing. There is an increasing number of cases of stress and depression experienced by residents of the city of Jakarta, especially those in low-income groups who live in dense settlements, such as in Johar Baru, Central Jakarta. While there is a close relationship between space and human psychological health, and how architecture can play a role in helping a person's healing process, through stimulation that triggers the release of hormones from the human brain as brain pharmaceuticals. This study aims to produce a concept and design of mental health facility buildings that can assist the community in preventing and coping with stress both on a community and individual scale. By using an environmental healing approach, the design will emphasize the direct and indirect connectivity between the environment, buildings and humans. So that it can support the healing process from feeling depressed, depressed and stressed by users.
\end{abstract}

Keywords: healing architecture; urban stress; natural environment; public space

\section{PENDAHULUAN}

\section{Latar Belakang}

Kepadatan kota Jakarta terus meningkat setiap tahunnya, menjadikan kota Jakarta sebagai kota yang sibuk, bising, ramai, dan kompetitif. Ruang terbuka hijau semakin berkurang, digantikan dengan 
gedung pencakar langit dan kawasan permukiman, serta jalan-jalan dipenuhi oleh kendaraan bermotor. Akibat modernisasi serta globalisasi, terjadi perubahan sosial pada kehidupan masyarakat yang menimbulkan kecenderungan masyarakat sulit untuk beradaptasi dengan lingkungan tempat tinggalnya. Maka, timbul kebingungan, kecemasan, dan konflik lainya baik secara eksternal maupun internal yang berpengaruh terhadap tindakan atau perilaku yang menyimpang. Keadaan ini secara tidak langsung menimbulkan banyak permasalah urban yang baru, termasuk kesehatan mental masyarakat perkotaan, yaitu depresi atau stress.

Indonesia masih kekuranagan fasilitas kesehatan mental, dan kurangnya perhatian terhadap masalah kesehatan mental (stress dan depresi). Di lihat dari sisi psikologis, faktor lingkungan berperan penting dalam proses penyembuhan. Pendekatan healing environment adalah konsep holistik yang bertujuan untuk menghindari penderita depresi dan pengunjungnya terpapar stres yang akan menghambat proses penyembuhan. Untuk itu perlunya pengaturan hubungan antara alam, manusia, dan bangunan yang mendukung proses penyembuhan. Penelitian di bidang ini dilakukan di bidangbidang berikut:

a. Hubungan pasien / keluarga dengan alam

b. Dukungan sosial dan emosional

c. Penguranggan stres di lingkungan fasilitas kesehatan

d. Gangguan Informasi pasien dan perubahan perilaku

Pendekatan tersebut menyiratkan bahwa lingkungan untuk perawatan kesehatan dapat membuat perbedaan dalam kesehaatan jiwa penderita untuk pulih dari atau beradaptasi dengan kondisi akut dan kronis tertentu. Oleh karena itu, diperlukan suatu wadah yang dapat mendukung kesehatan mental masyarakat dan memberikan lingkungan yang nyaman dan sehat untuk penderita depresi dalam berobat. Serta meningkatkan kesadaran masyarakat akan pentingnya kesehatan jiwa dan menghilangkan stigma negatif pada penderita gangguan jiwa. Sehingga terciptanya ikatan sosial yang kuat dan nyaman antara masyarakat dan penderita depresi.

\section{Rumusan Permasalahan}

a. Bagaimana ekspresi fasilitas kesehatan ini mampu mendorong penderita depresi untuk datang terlepas dari stigma negatif dari masyarakat mengenai gangguan mental emosional?

b. Bagaimana rancangan bangunan dan ekspresi arsitektur pada suatu fasilitas kesehatan mental mampu membantu kesembuhan penderita gangguan mental, sekaligus dapat melepaskan diri dari stigma negatif melalui edukasi kepada masyarakat?

\section{Tujuan}

Tujuan proyek ini adalah mengusulkan konsep dan perancangan wadah untuk membantu warga masyarakat, terutama dalam mengatasi masalah stress dan depresi yang dialami warga yang terdampak pandemi Covid-19 dan bencana lain (wabah penyakit, krisis ekonomi, dan bencana alam dan sebagainya) di masa mendatang. Dalam keadaan normal, fasilitas ini bertujuan untuk mendorong masyarakat agar memperhatikan kesehatan mentalnya, sekaligus dapat mengakomodir aktivitas masyarakat di Johar Baru dan sekitarnya untuk memperkuat komunitas yang tangguh dalam menghadapi bencana di masa mendatang.

\section{KAJIAN LITERATUR}

\section{Kesehatan Mental Saat Pendemi}

Pandemi Covid-19 telah mengubah struktur kehidupan masyarakat, termasuk tata ruang kota dan arsitektur. Setelah pandemi usai, semua pihak terkait perlu menyiapkan rencana kota yang lebih sehat untuk mengantisipasi pandemi serupa terulang kembali. Keterbatasan bangunan dan ruang multifungsi yang dapat digunakan sebagai tempat karantina atau isolasi ditengah kawasan 
permukiman yang padat, sebagai salah satu contoh penataan ruang kota yang lebih baik untuk kondisi krisis di masa mendatang (Kontan,2020).

Pada saat pendemi seperti ini banyak tekanan yang muncul sehingga meningkatkan depresi. Menurut Sekretaris Jenderal PBB, Antonio Guterres orang yang berisiko terkena depresi adalah tenaga medis, orang tua, remaja, dan orang muda (Koran Tempo,2020). Di setiap komunitas, ada banyak lansia dan orang dengan kesehatan yang buruk mengalami ketakutan dan kesepian. Anak-anak dan remaja juga mengalami kesulitan emosional yang diperburuk dengan adanya tekanan keluarga, isolasi sosial, serta beberapa menghadapi peningkatan pelecehan, pendidikan yang terganggu dan ketidakpastian tentang masa depan mereka, yang dialami pada masa perkembangan emosional mereka.

Beberapa negara mengalami peningkatan kasus kesahatan mental dengan gejala depresi dan kecemasan. Untuk mengatasi stress, penderita depresi menggunakan berbagai cara negatif termasuk penggunaan alkohol, narkoba, tembakau, atau menghabiskan lebih banyak waktu untuk perilaku yang berpotensi membuat ketagihan seperti bermain game online. Berdasarkan pemeriksaan mandiri terhadap 1.522 orang yang dilakukan oleh Perhimpunan Dokter Spesialis Kedokteran Jiwa Indonesia (Republika, 2020), sebanyak 64,3\% mengalami depresi selama pendemi ini. Pada saat yang sama, menurut penelitian yang dilakukan oleh yayasan amal Youngminds menunjukan $80 \%$ remaja dan dewasa muda menderita depresi.

\section{Depresi}

Depresi merupakan satu kondisi terganggunya fungsi manusia yang berkaitan dengan perubahan suasana hati yang memunculkan gejala yang tidak kunjung hilang, termasuk perubahan pola tidur dan nafsu makan, psikomotor, konsentrasi, anhedonia, kelelahan, rasa putus asa dan tidak berdaya, serta keinginan untuk bunuh diri (Kaplan, 2010). Menurut Rosenvald, Oei, dan Schmidt (2007) menjelaskan depresi sebagai kondisi yang menyebabkan perubahan dalam diri individu dalam segi suasana hati (merasa tidak berharga), tingkah laku (mudah marah atau menarik diri dari interaksi dengan orang), fungsi diri (sulit berpikir dan konsentrasi), dan kondisi fisik (sulit tidur atau terlalu banyak tidur), serta perubahan berat badan. Maka dapat disimpulkan pengertian depresi adalah suatu keadaan ketika individu mengalami gejala-gejala yaitu perasaan sedih, tertekan, kesepian, berkurang nafsu makan, membutuhkan usaha lebih besar dalam melakukan sesuatu, kesulitan tidur, merasa cemas, tidak bersemangat, dan merasa ditolak dalam lingkungan sosial. Jenis-jenis depresi menurut American Psychiatric Association (2013) dan Rosenvald, Oei, \& Schmidt (2007), berdasarkan tingkat penyakitnya, adalah:

\section{- Mild depression/minor depression dan dysthymic disorder}

Pada depresi ringan, perubahan suasana hati dan perilaku berlangsung selama beberapa hari dan depresi ini datang setelah kejadian traumatis atau mengalami tekanan batin. Individu akan merasa cemas dan juga tidak bersemangat. Jenis depresi ringan disebut gangguan distimia (dystymic disorder). Dalam jangka waktu yang lama, depresi ini dapat menyebabkan depresi ringan sehingga seseorang tidak dapat bekerja optimal. Gejala depresi ringan ada gangguan distimia dirasakan minimal jangka waktu dua tahun. Perubahan gaya hidup dapat membantu dalam meningkatkan kadar serotonin dalam otak, yang dapat mencegah gejala depresi.

\section{- Moderate depression}

Pada depresi sedang, perubahan suasana hati dan perilaku yang rendah berlangsung terusmenerus dan individu mengalami gejala fisik walaupun berbeda-beda tiap individu. Individu akan mengalami kesulitan yang signifikan dalam kehidupan sosial dan gejalanya sangat mempengaruhi kehidupan sehari-hari. Perubahan gaya hidup saja tidak cukup dan diperlukan perawatan medis untuk mengatasinya. 


\section{- Severe depression/major depression}

Depresi berat ditandai dengan suasana hati yang tertekan hampir sepanjang hari, dan hilangnya minat pada aktivitas dan hubungan normal. Gejala pada depresi berat muncul setiap hari selama dua minggu. Individu akan mengalami kesulitan tidur, berkurang nafsu makan, tidak dapat bekerja optimal dan menikmati hal-hal yang menyenangkan, sehingga penting untuk mendapatkan bantuan medis sesegera mungkin.

\section{METODE}

Metode perancangan yang digunakan pada studi ini adalah pendekatan Healing Environment. Menurut Knecht (2010), healing environment merupakan suatu tatanan fisik dan dukungan budaya yang memelihara fisik, intelektual, sosial, dan kesejahteraan spiritual pasien, keluarga, dan orang di sekitarnya, dalam membantu penderita mengatasi stres atau depresinya. Healing Environment merupakan sebuah lingkungan yang dirancang untuk menciptakan harmoni antara pikiran, tubuh, dan jiwa. Dalam penerapan healing environment sangatlah diharuskan untuk menjaga dari unsur psikologis penderita, diantaranya adalah; alam, indera, dan psikologi. Sehingga healing environment dapat membantu pemulihan, mengurangi rasa sakit, dan depresi atau stress. Menurut Ralene van der Walt dan Ida Breed (2012), prinsip - prinsip healing environment adalah:

a. Independence (kebebasan/ keleluasaan)

Desain yang dirancang dapat memberi rasa kemandirian pada pengguna dengan meningkatkan kepercayaan diri mereka. Perancangan bertujuan untuk menyediakan tempat untuk pribadi maupun berkelompok untuk saling berinteraksi. Serta penggunaan material yang memberikan batas visual seperti struktur, tanaman dan perbedaan material lantai.

b. Consciousness (kesadaran)

Lingkungan membantu orang yang mengalami depresi dan stress untuk sadar dan lebih bersosialisasi dengan lingkungan sekitar mereka, hal ini dicapai dengan merangsang indera manusia (multi sensory architecture).

c. Connectedness (kesinambungan)

Proses penyembuhan untuk penderita depresi biasanya dilakukan di rumaah sakit jiwa yang identik dengan isolasi fisik dan sosial. Oleh karena itu, bangunan dirancang untuk mendorong rasa terhubung dengan mengakomodasi aksesibilitas. Interaksi sosial dan kontak dengan alam sekitar, hubungan dengan alam dapat dicapai dengan adanya taman yang digunakan untuk berkumpul dan terapi hortikultura. Bangunan dirancang terbuka terhadap umum, namun tidak membahayakan keselamatan orang yang mengalami depresi atau hubungan dengan publik.

d. Purpose (tujuan)

Desain mampu memberikan kesempatan dan mewadahi kegiatan penderiita depresi untuk ikut terlibat dalam lingkungannya, contohnya dengan pengadaan taman untuk terapi hortikultura.

e. Physical Activities (kegiatan fisik)

Lingkungan menyediakan wadah untuk aktivitas fisik dan olahraga, karena secara khusus bersifat terapi untuk penderita depresi dan stress. Desain mencakup rute untuk berjalan atau jogging, gym dan senam yang mampu memberikan pengalaman sensorik terhadap penggunanya.

f. Restorative (pemulihan)

Lingkungan yang sejuk dan cerah dapat dijadikan sebagai area istirahat atau bersantai, selain itu material yang digunakan memiliki tekstur yang halus dan tidak silau. Menyediakan tempat tenang dimana pasien memiliki privasi jauh dari kegiatan utama, ruang meditasi dan konseling untuk penderita depresi dirancang agar memiliki suasana tenang dengan menggunakan pelingkup yang tahan kebisingan.

\section{DISKUSI DAN HASIL}

\section{Lokasi}

Lokasi proyek ini dipilih di Johar Baru, karena mempunyai kepadatan penduduk yang tinggi, keadaan ekonomi yang rendah, pengangguran tinggi dan tak tersedianya ruang interaktif merupakan 
sebagian penyebab konflik di kawasan pemukiman padat tersebut. Faktor-faktor tersebut menjadi pertimbangan untuk pemilihan lokasi studi sebagaimana tercantum dalam gambar 1 .
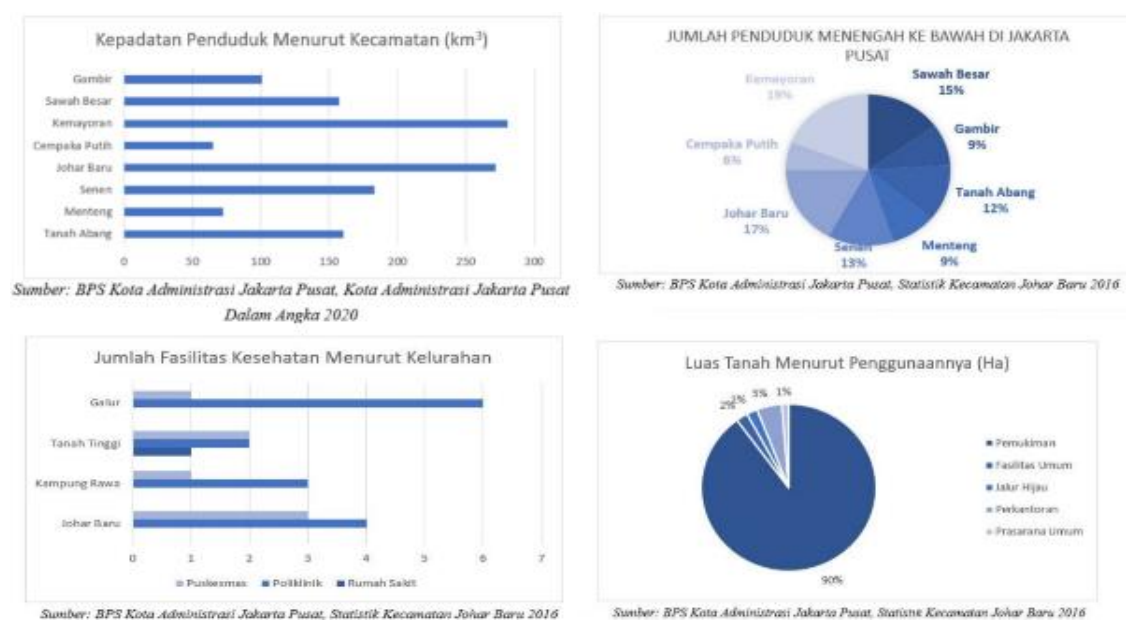

Gambar 1. Faktor Faktor Yang Mempengaruhi Pemilihan Tapak Sumber : BPS Kota Administrasi Jakarta Pusat, 2020

Kecamatan Johar Baru termasuk daerah padat penduduk, kepadatannya mencapai 60.933 jiwa $/ \mathrm{km}^{2} /$ kapita menjadikannya sebagai kecamatan terpadat di Jakarta. Penataan rumah yang berdesakan, tidak adanya fasilitas pembuangan air dan sampah yang memadai mengakibatkan penduduk buang sampah dan buah limbah disembarang tempat, anak-anak bermain di jalanan, serta lingkungan yang terlihat kotor dan kumuh. Kondisi lingkungan yang kurang baik akan mempengaruhi kesehatan masyarakat, terutama kesehatan mental dari masyarakat yang tinggal di kawasan tersebut.

Tapak berada pada Jl. Pulo Gundul No.122, diantara hunian padat yang cenderung memiliki ketinggian yang sama (2 tingkat). Batas tapak ditentukan dari jalan (path) untuk sirkulasi warga masuk dan keluar hunian. Tapak berdekatan dengan tempat transit kendaraan umum (stasiun) serta berseberangan dengan Sungai Sentiong pada arah barat.

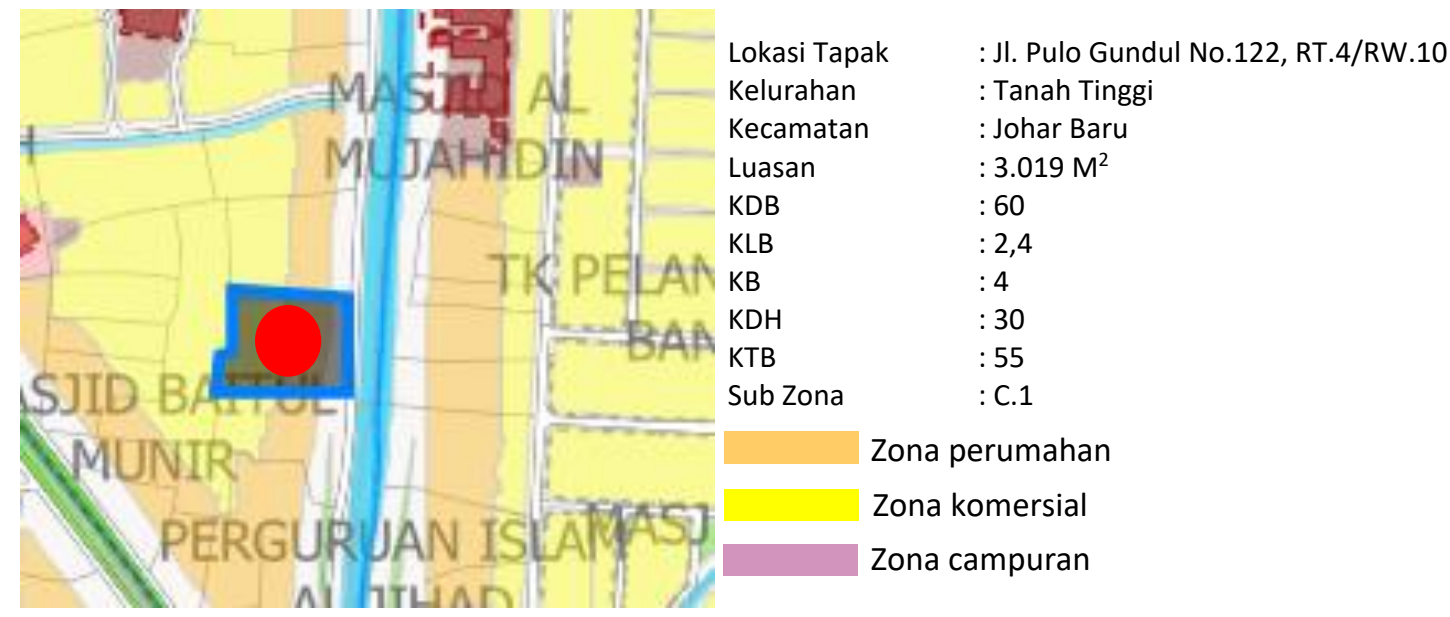

Gambar 2 Data Tapak

Sumber: Jakartasatu, 2020 

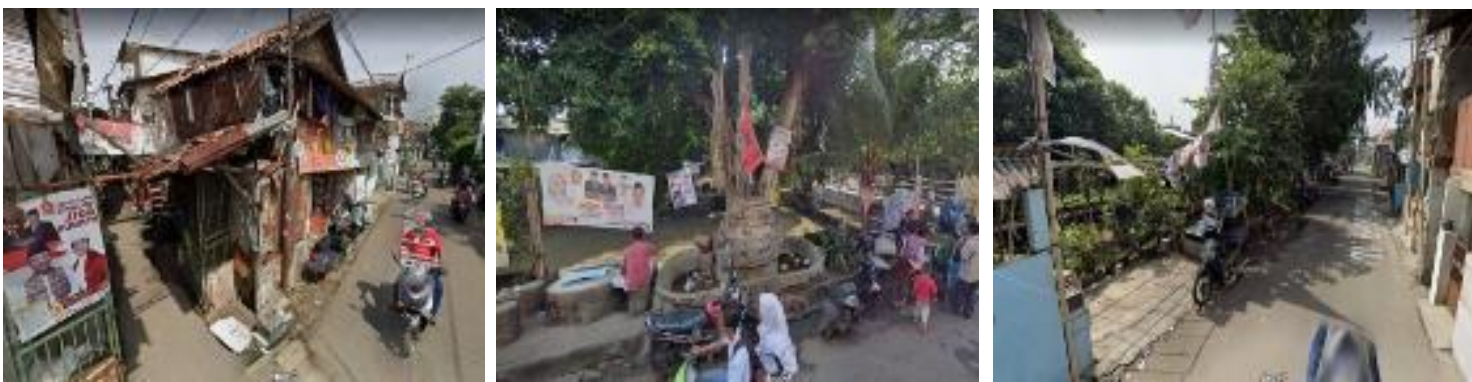

Gambar 3 Lingkungan Sekitar Sumber: Google Maps , 2020
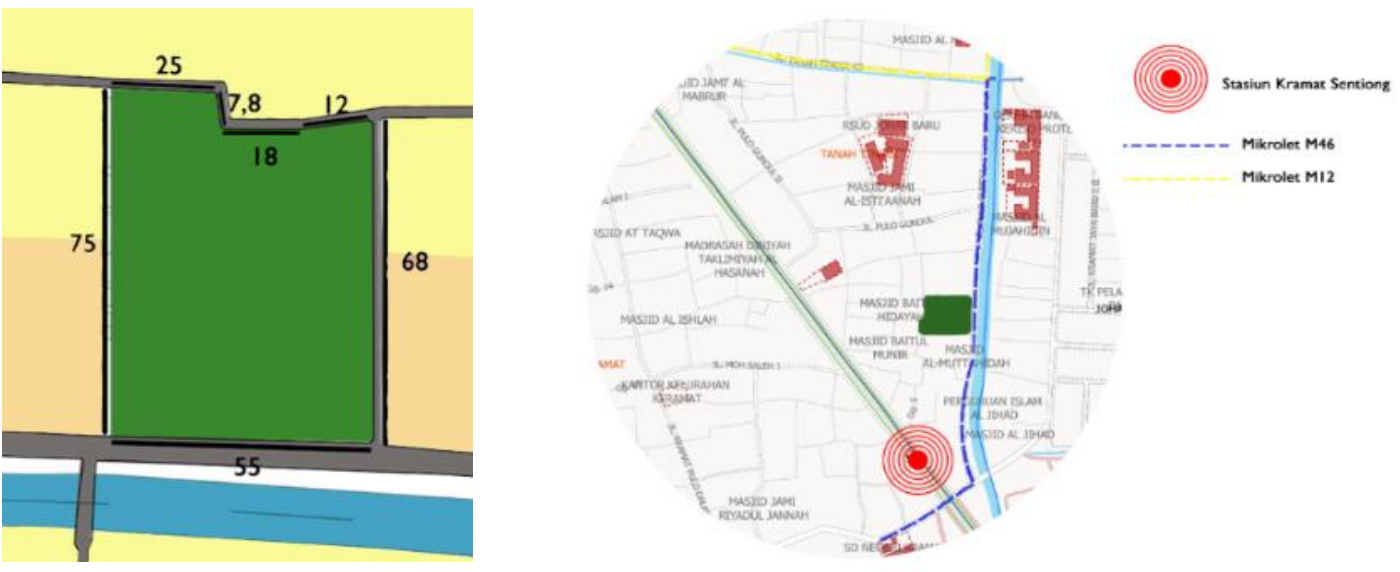

Gambar 4 Ukuran Tapak Dan Jalur Transportasi Sumber: Jakartasatu, 2020

Lokasi tapak berjarak 350 meter dari stasiun Kramat Sentiong. Akses transportasi disekitar tapak yang berhadapan dengan jalan cukup memadai. Entarnce dapat diakses melalu jalan depan tapak yang memiliki lebar 6 meter. Sedangkan jalan di sisi utara dan barat dapat dijadikan akses untuk pejalan kaki dari kawasan permukiman. Kebisingan berasal dari rumah warga yang berada disekitar tapak serta kendaraan yang melewati jalan disekitar tapak. Kebisingan ini dapat di atasi dengan meletakan area hijau. View dari tapak yaitu sungai yang berada di depan tapak serta kawasan permukiman yang berada di sisi kiri-kanan dan belakang tapak.

\section{Konsep Perancangan}

Bangunan fasilitas ini dirancang untuk berfungsi sebagai ruang pereda depresi bagi masyarakat sekitar. Pendekatan yang dilakukan dengan memberi ruang kreatif dan edukatif yang bersifat menyenangkan, ramah anak, dan menekankan ilmu budaya dan seni sekitar kawasan. Desain dirancang dengan mengutamakan ruang terbuka hijau pada bangunan. Bangunannya juga tidak bersifat masif atau tertutup, melainkan bersifat terbuka sehingga komunikasi antara ruang luar dan dalam dapat terjalin.

a. Wholeness of the Universe atau segala material dan ruang yang ada dianggap sebagai keseluruhan, dimana faktor pembentuk yang kelihatan maupun tidak tetap di pertimbangkan. (Pada gambar 5)

b. The basic form is an oval atau bentuk dasar dari bangunan ini berbentuk oval, bentuk yang kita kenal sebagai bentukan yang rileks dan memiliki arti keutuhan, mencakup atau mengelilingi semua. (Pada gambar 5)

c. Surrounding and centre, yang dimaksudkan adalah bangunan dirancang untuk mendorong rasa terhubung dengan mengakomodasi antara ruang sekitar atau pinggiran dan ruang tengahannya dengan permainan bentuk ruang. (Pada gambar 5 ) 
d. Covering, Skin, Bark, Wall yang memiliki maksud adanya penutup dan pembatas antara ruang luar dan dalam. (Pada gambar 5)

e. Principle of Emptiness in the centre, prinsip-prinsip kekosongan atau void yang terletak di bagian tengah, yang memberikan energi konsentrasi. (Pada gambar 5)

$\mathrm{f}$. The Life Force is connected with surface, bangunan dirancang untuk mendorong rasa terhubung dengan mengakomodasi aksesibilitas, interaksi sosial dan kontak dengan alam sekitar. (Pada gambar 5)

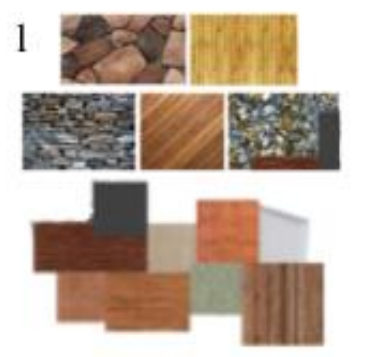

2

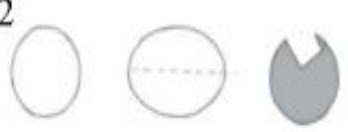

3

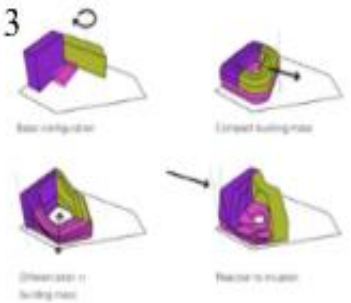

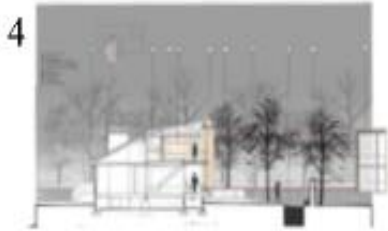

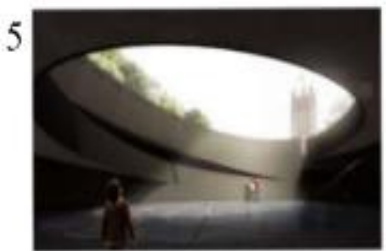

6

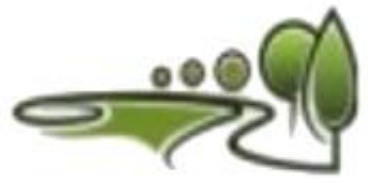

Gambar 5 Konsep Perancangan

Sumber: Google Image, 2020

\section{Program Kegiatan}

Untuk menciptakan ekosistem inovasi maka program dibuat tidak hanya mementingkan kepentingan pasien tetapi masyarakat di sekitarnya. Program disesuaikan dengan aktivitas-aktivitas yang biasa dilakukan di sekitar kawasan dan juga dari kebutuhan, serta luasan didasarkan oleh analisa-analisa data tapak, mulai dari aktivitas sehari- hari pengunjung atau masyarakat sekitar. Program - program proyek antara lain :
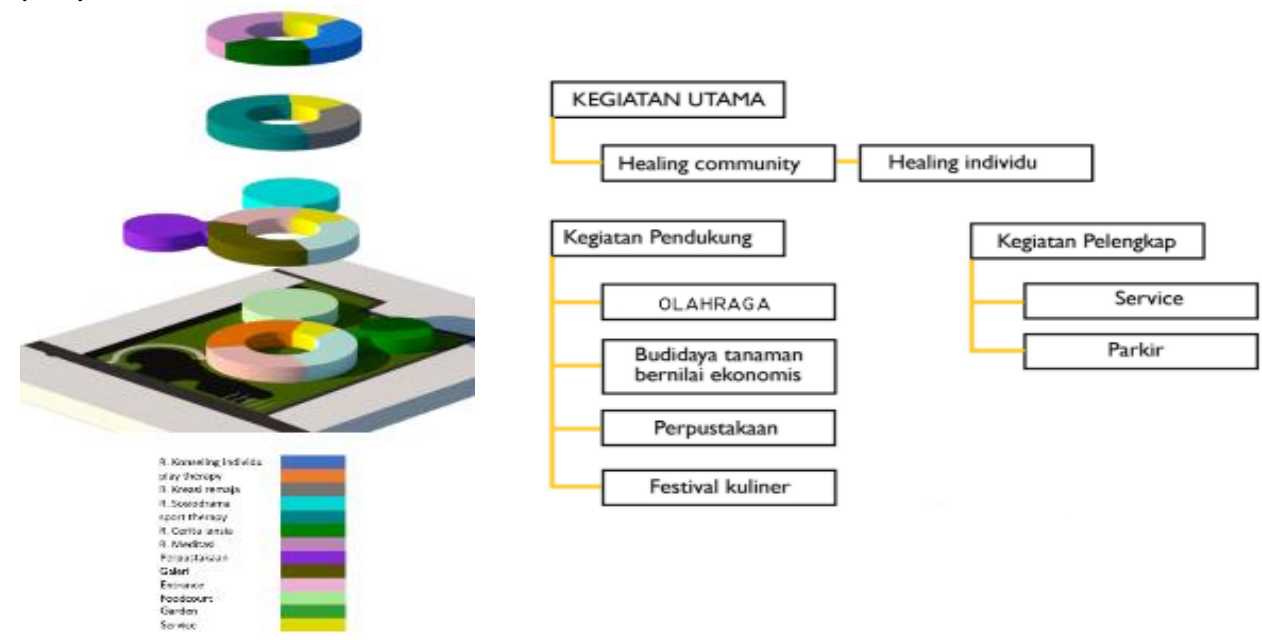

Gambar 6. Zoning

Sumber : Penulis, 2020 

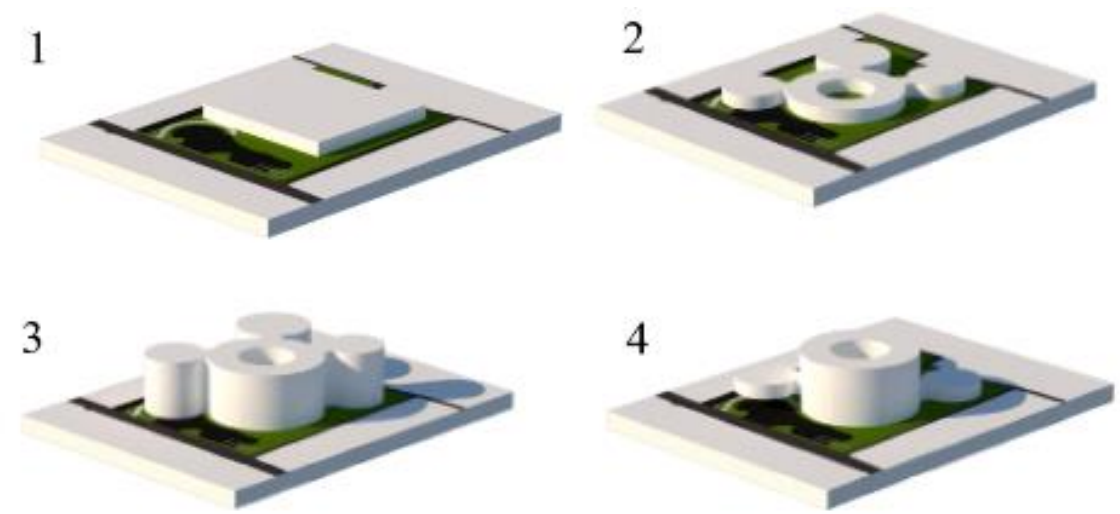

Gambar 7. Gubahan massa

Sumber : Penulis, 2020

\section{Konsep dan Hasil Perancangan Eksterior}

Pada gambar eksterior bangunan dapat terlihat material menggunakan kayu, di lantai dasar bangunan bahkan tidak ada dinding masif yang menghalangi masyarakat yang berkunjung, lantai dasar massa utama menggunakan kisi-kisi kayu sebagai pembatas ruang yang tetap memberi kesan privat namun tidak tertutup sepenuhnya.
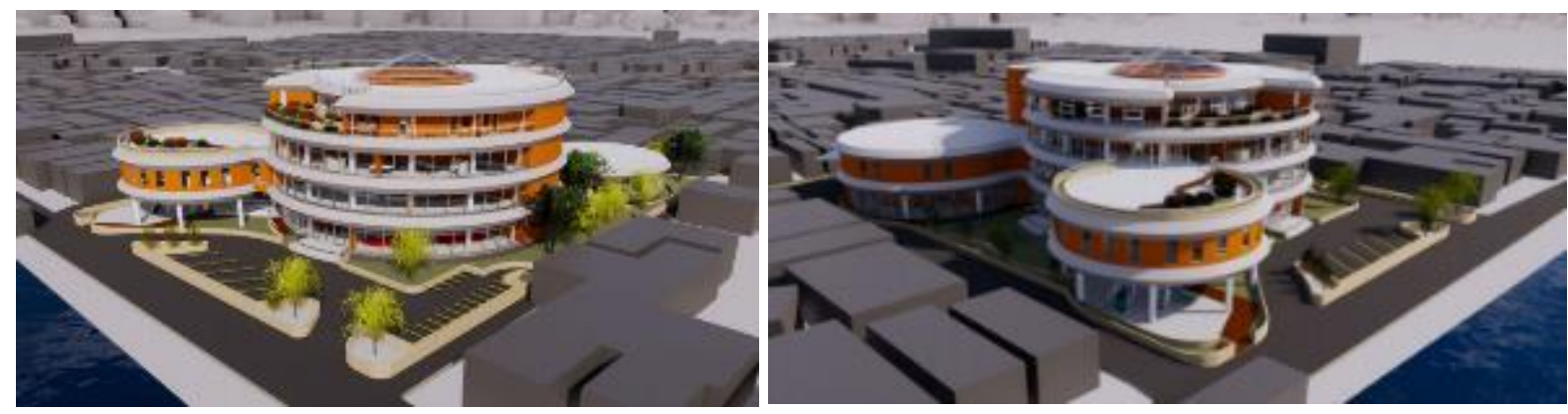

Gambar 8. Eksterior

Sumber : Penulis, 2020

\section{Konsep dan Hasil Perancangan Interior}

Interior bangunan terlihat sangat mengandalkan cahaya dan pengudaraan alami yang dapat meredakan tingkat stress seseorang. Penggunaan material kayu juga berefek bagi psikologis manusia, seperti berada di alam. Penggunaa ramp sebagai sirkulasi vertikal juga sengaja di buat supaya memberi kesan santai saat menaiki ramp. Adanya pencahayaan di tengah massa bertujuan unntuk menghantar warga yang ada di luar ruangan ke dalam ruangan.
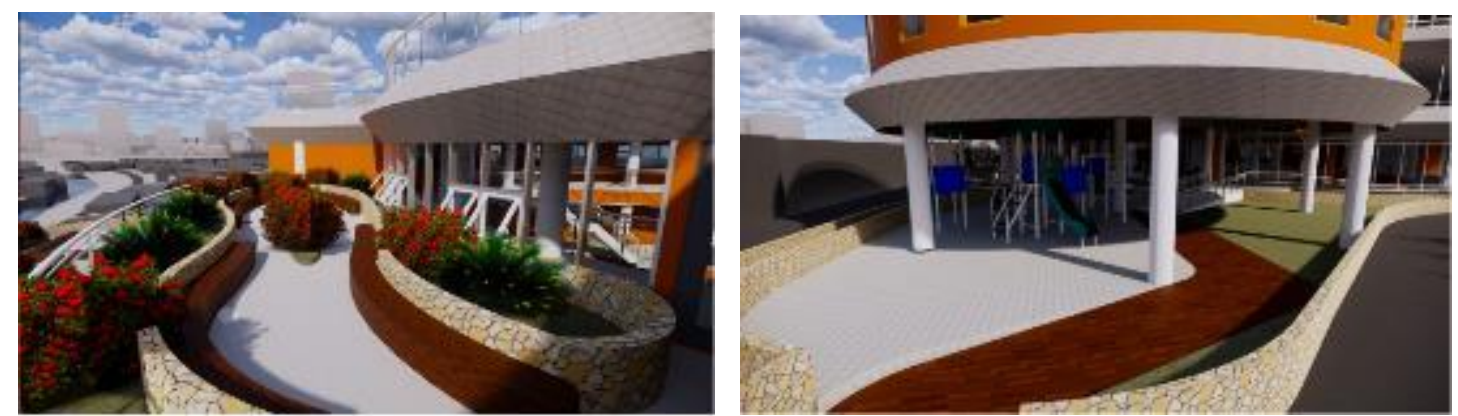

Gambar 9. Interior

Sumber : Penulis, 2020 


\section{KESIMPULAN DAN SARAN}

\section{Kesimpulan}

Dalam studi serta analisis yang telah dilakukan terhadap teori, data kawasan serta fenomena yang terjadi maka disimpulkan bahwa:

- Proyek dwelling ini difungsikan sebagai sarana kesehatan jiwa dan dibangun sesuai dengan kebutuhan masyarakat sekitar yang dilihat dari permasalahan, karakteristik atau potensi di kawasan Johar Baru. Permasalahan wilayah Johar Baru antara lain kepadatan penduduk, tingkat ekonomi rendah dan permasalahan sosial.

- Dengan memanfaatkan sumber daya lokal, meningkatkan lingkungan dan berinteraksi atau bersosialisasi masyarakat yang berkelanjutan dapat terwujud. Proyek dwelling ini didasarkan pada nilai healing environment, yakni unsur alam, indra, dan psikologis manusia yang saling mempengaruhi. Dari nilai tersebut terbentuk program bangunan, yaitu mental health area, zona edukasi dan zona komunitas. Ketiga program terpadu tersebut merupakan aktivitas dalam bangunan yang mempunyai nilai hiburan, jasa dan edukasi

\section{Saran}

Diharapkan, melalui wadah ini, dapat mengurangi masalah depresi bahkan jenuh yang dialami masyarakat sekitar, serta dapat meningkatkan kualitas hidup masyarakat menjadi lebih baik dengan aktivitas dan program di wadah ini.

\section{REFERENSI}

American Psychiatric Association. (2013). Diagnostic and Statistical Manual of Mental Disorders (Fifth Edition-Text Revision): DSM-V-TR. Washington DC: American Psychiatric Association

Knecht, M. L. (2010). Optimal Healing Environments. Healthy Communities by Design: Redlands and Loma Linda, CA. https://proceedings.esri.com/library/userconf/healthycommunities10/pdfs/optimal-healing-environments.pdf

Kaplan, H. I. (2010). Ilmu Kedokteran Jiwa Darurat. Jakarta: Widya Medika.

Rosenvald, T., Oei, T. P. S. \& Schmidt, M. (2007). Flight Your Dark Shadow: Managing Depression with Cognitive Behaviour Therapy (I. Saraswati, trans). Brisbane: Depression Managed.

Ralene van der Walt and Ida Breed, 2012. "The mindful landscape: a healing outdoor experience for Weskoppies psychiatric hospital”. Vol 27, no. 2. http://hdl.handle.net/2263/21190

VOA Indonesia. (2020). Dampak Pendemi Terhadap Dunia Arsitektur, diambil dari https://www.voaindonesia.com/a/in-case-you-missed-it-dampak-pandemi-terhadap-duniaarsitektur-/5501425.html

Kontan. (2020). Ahli: Pandemi Corona Akan Mengubah Struktur Tata Ruang Kota, diambil dari https://nasional.kontan.co.id/news/ahli-pandemi-corona-akan-mengubah-struktur-tata-ruangkota

Koran Tempo. (2020). Dunia Terancam Krisis Mental Global, diambil dari https://koran.tempo.co/read/internasional/452962/pandemi-corona-akibatkanmeningkatnya-krisis-mental?

Republika. (2020). 64,3 Persen Responden Depresi Terkait Pandemi, diambil dari https://republika.co.id/berita/q9mz2e328/643-persen-responden-depresi-terkait-pandemi 